\title{
Tekrarlayan Hışıltı Nedeni Olarak Parainfluenza Tip 3 Virüsü
}

\author{
Parainfluenza Type 3 Virus as an Etiological Cause of Recurrent Wheezing

\section{Öner Özdemir ${ }^{1}$, Ece Cansu Okur ${ }^{2}$} \\ ${ }^{1}$ Sakarya Üniversitesi Tip Fakültesi Çocuk Immünoloji-Allerji BD, Eğitim ve Araştırma Hastanesi, Sakarya \\ ${ }^{2}$ Sakarya Üniversitesi Tip Fakültesi Çocuk Sağlğ̆ı ve Hastalıkları Anabilim Dalı, Eğitim ve Araştırma Hastanesi, Sakarya
}

Yazıșma Adresi / Correspondence:

Prof. Dr. Öner Özdemir

Çocuk İmmünolojisi ve Alerji Hastalıkları Bölümü, Sakarya Üniversitesi Tip Fakültesi Sakarya Üniversitesi Eğitim ve Araştırma Hastanesi Adnan Menderes Cad., Sağlık Sok. No: 195 Adapazarı, Sakarya

T: + $902644445400 \quad$ E-mail: ozdemir_oner@hotmail.com

Orcid

Öner Özdemir https://orcid.org/0000-0002-5338-9561

Ece Cansu Okur http://orcid.org/0000-0003-0297-9788

Geliş Tarihi / Received : 17-09-2019 Kabul Tarihi / Accepted : 14-10-2019 Yayın Tarihi / Online Published: 27-12-2019

Özdemir Ö., Okur E.C., Tekrarlayan Hışıltı Nedeni Olarak Parainfluenza Tip 3 Virüsü,

J Biotechnol and Strategic Health Res. 2019;3(3):260-263 DOI: 10.34084/bshr.621051

Özet

Tekrarlayan hıșltı șikâyeti ile polikliniğe bașvuran ve nazofaringeal sürüntüden etyolojik ajan olarak Parainfluenza Tip 3 virüsü elde edilen 8 yașında kız hasta sunulmaktadır. Dört gündür öksürük ve hırıltı șikâyeti ile dıs merkeze götürülen hasta orada bașlanan tedaviye rağmen hırıltı șikâyetinin artması nedeni ile Cocuk Alerji ve İmmünoloji Polikliniği’ne getirildi. Özgeçmişinde tekrarlayan hışıltıya yol açmış çok sayıda bronşiolit tanısı ile salbutamol alma ve aralıklı montelukast kullanım öyküsü mevcuttu. Hastanın yapılan fizik muayenesinde bilateral sibilan ronküs, ekspiryum uzunluğu ve sukrepitan/kaba ralleri olması nedeniyle ve ileri tetkik- tedavi için Çocuk Alerji ve İmmünoloji Servisi’ ne yatıșı yapıldı. Laboratuvar tetkiklerinde lökopeniyle beraber lenfopeniye ek olarak monositoz gözlendi. Kliniğin düzelmesiyle lökosit, lenfosit ve monosit sayıları normal sınırlara indi. Hastaya salbutamol, ve ipratropium bromür nebül tedavisi başlandı. Nazofarenks sürüntüsünde Parainfluenza Tip 3 virüsü izole edildi. Parainfluenza virüs enfeksiyonları; çocukluk çağı tekrarlayan bronşioliti, astımı ve hışıltı gibi kronik hava yolu hastalıklarının viral alevlenmelerinin önemli nedenlerinden olup klinisyenler tarafindan akılda tutulmalıdır.

Anahtar Hıșltı, Parainfluenza, bronșiolit

Kelimeler

Abstract

An 8-year-old female patient with a complaint of recurrent wheezing presented to the outpatient clinic that Parainfluenza Tip 3 Virus (PIV-3) as an etiological agent was obtained from nasopharyngeal swab. Patient was taken to pediatric allergy and immunology clinic despite the fact that he did not respond to the therapy given by outside center and the wheezing complaint increased within last 4 days. There were many bronchiolitis attacks in her past medical history requiring salbutamol and intermittently montelukast use. He was admitted to pediatric allergy and immunology service for further evaluation and therapy after physical examination showed bilateral sibilant rhonchi, expirium elongation and had subcrepitant/rough rales. Laboratory results showed not only leukopenia but also lymphopenia plus monocytosis. Leukocyte, lymphocytes and monocytes numbers became normal after the patient clinical table improved. Salbutamol and ipratropium bromide nebul therapy was started. PIV-3 was isolated from her nasopharyngeal swab. Clinicians should keep in mind that viral infections such as Parainfluenza are important triggers for attacks of chronic airway diseases e.g. recurrent bronchiolitis, asthma and wheezing seen during childhood.

Keywords Wheezing, Parainfluenza, bronchiolitis 


\section{GIIRIŞ}

Akut bronşiolit, özellikle iki yaş altı çocuklarda alt solunum yollarının en sık görülen hastalığıdır ve küçük hava yollarının enflamatuvar obstrüksiyonu sonucu ortaya çıkar. Akut bronşiolit, kış aylarında ve ilkbahar başlarında diğer mevsimlere göre daha sık görülmektedir. Akut bronşiolit sıklıkla viral patojenlerin yol açtığı bir hastalıktır. ${ }^{1}$ Viral solunum yolu enfeksiyonlarının etkenleri Respiratuvar Sinsisyal Virüs (RSV), İnfluenza, Parainfluenza virüs (PİV), Adenovirüs, Rinovirüs, Koronavirüs ve insan Metapnömovirüs (iMPV) dür. ${ }^{2}$ En sık viral etken RSV olup; PİV en sık 5 yaş altı çocuklar arasında akut solunum yolu enfeksiyonlarının en sık nedenlerindendir. ${ }^{3}$ Burada tekrarlayan hışıltı şikâyeti ile polikliniğe başvuran ve tedavi için yattığı sırada etyolojik ajan olarak nazofaringeal sürüntüden PİV tip 3 (PİV-3) elde edilen 8 yaşında bir hasta sunulmuştur.

\section{Olgu}

Sık bronşit/bronşiolit geçirme öyküsü olan 8 yaşındaki kız hasta 4 gündür öksürük, hırıltı şikâyetlerinin olması nedeni ile dış merkeze başvurmuştu. Hastaya amoksisilin-klavulanat, klaritromisin, salbutamol ve flutikazon nebül tedavisi başlanmıştı. Verilen tedaviyi kullanmasına rağmen öksürük, hırıltı şikâyetlerinde artış olması nedeni ile Çocuk Alerji ve İmmünoloji polikliniğine başvurmuştu. Hastanın yapılan fizik muayenesinde bilateral sibilan ronküs, ekspiryum uzunluğu ve sukrepitan/kaba ralleri olması nedeni ile ileri tetkik-tedavi amacı ile Çocuk Alerji ve İmmünoloji Servisi’ ne yatışı yapıldı. Özgeçmişinde tekrarlayan hışıltıya yol açmış çok sayıda (15-20 kez) bronşiolit tanısı ile salbutamol alma ve aralıklı montelukast kullanım öyküsü mevcuttu. Soy geçmişinde ailede bilinen bir hastalık öyküsü yoktu. Fizik muayenesinde solunum sisteminde; akciğer sesleri bilateral eşit, yaygın kaba ralleri ve ronkus mevcut olup ekspiryum uzunluğu vardı. Kardiyovasküler sistem muayenesi ve batın muayenesi doğaldı. Nörolojik muayenede bilinç açık, ense sertliği ve meningeal irritasyon bulgusu yoktu. Hastaya salbutamol 4x1.5 nebül, ipratropium bromür $4 \times 1$ nebül, ve akut faz reaktan- ları hala yüksek olduğu için önceden başlanan antibiyoterapi Seftriakson $100 \mathrm{mg} / \mathrm{kg} /$ gün (iki dozda) ve klaritromi$\sin 15 \mathrm{mg} / \mathrm{kg} /$ gün (2 dozda) tedavisi devam edildi.

Laboratuvar incelemelerinde; Hgb: 12.9 g/dL, Hct: \% 38.9, lökosit: 2.150 /mm3 idi. Nötrofil: \% 70.7, lenfosit: \% 4.26, monosit: \% 20.5, eozinofil: \% 3.22 idi. AST: 28 U/L, ALT: $16 \mathrm{U} / \mathrm{L}$, üre: $20 \mathrm{mg} / \mathrm{dL}$, kreatinin: $0,31 \mathrm{mg} / \mathrm{dL}$ olup, diğer biyokimyasal tetkikleri de normal sınırlarda idi. C-Reaktif protein (CRP): $24.7 \mathrm{mg} / \mathrm{L}(0-5)$, eritrosit sedimantasyon hızı: $35 \mathrm{~mm} /$ saat olarak saptand1. Sık sık bronşiolit nedenli hastane başvurusu olan hastanın bakılan serum immunglobulin düzeyleri normal olup serum immunoglobulin (Ig) G: 11.2 g/L (6.39-13.4), IgA: 1.46 g/L (0.7-3.12), IgM: $1.79 \mathrm{~g} / \mathrm{L}(0.56-3.52)$ ve IgE: <17,3 IU/mL (0-90) olarak saptandı. Yatışta hastanın viral-bakteriyel ajanlara yönelik solunum paneli tetkikleri alındı. 9 virüs grubundan (İnfluenza, Rinovirüs, Koronavirüs, Pİ, iMPV A / B, Bokavirus, RSV, Adenovirüs ve Enterovirüs) toplam 18 virüs tarandı. Solunum paneli tetkikinden PIV-3 izole edildi.

Kontrol hemogram tetkiklerinde lökosit: $5.070 / \mathrm{mm} 3$, Hgb: 12.4 g/dL, Hct: \% 3.6, nötrofil: \% 38.2, lenfosit: \% 50.6, monosit: \% 8.7, eozinofil: \% 2.18 idi. CRP: $4.43 \mathrm{mg} / \mathrm{L}$ ve eritrosit sedimentasyon hızı: $23 \mathrm{~mm} / \mathrm{saat}$ bulundu. Tekrarlayan bronşiolite bağlı hışıltı atakları ve lökopenisinden dolayı primer immün yetmezliği dişlamak için istenen ileri immünolojik tetkiklerinden akım sitometri incelemesinde, hücresel bağışılklık elemanları olan T hücre, B hücre ve NK hücre sayıları normal saptandı. Kompleman C3, C4, CH50 kompleman aktivitesi testi, izohemagglütininler (anti-A, anti-B titresi), IgG alt grupları, geçmiş aşı yanıtları olan anti-HBs, anti-Rubella IgG, ve geçirilmiş enfeksiyona geliştirdikleri antikor yanıtları (anti-CMV IgG, , EBV-VCA IgG titreleri) istendi. Anti-HBs: pozitif (146.02), anti-CMV IgG: pozitif (>250), anti-Rubella IgG: pozitif (31.3), EBVVCA IgG: pozitif (>29.1) saptandı. Kompleman düzeyleri (C3: $1.2 \mathrm{~g} / \mathrm{L}, \mathrm{C} 4: 0.16 \mathrm{~g} / \mathrm{L}$ ) ve izohemagglütinin değerleri (anti-A: 1/64, anti-B: 1/256) normal aralıkta idi. Ig G alt grupları ve $\mathrm{CH} 50$ sonuçları da normaldi. 
Hastanın takiplerinde akciğer dinleme bulgularının gerilemesi nedeni ile nebül tedavisi kademeli olarak azaltıldı. Yatışının 6. gününde genel durumu ve akciğer dinleme bulguları düzelen hasta poliklinik kontrolü önerilerek taburcu edildi.

\section{Tartışma}

Çocuklarda alt solunum yolu enfeksiyonları (ASYE)' nın en sık nedenlerinden biri PİV' dir. İlk olarak 1950'li yılların sonlarında keşfedilen paramiksovirüs ailesinden olup, tek sarmallı RNA virüsleri grubundandır.4 Bu gruptaki üç ana tipi (tip 1, 2 ve 3), insan hastalıklarına neden olan virüslerdir.5 Sonbahar mevsiminde krup' a sebep olan tip 1 ve tip 2, en sık PİV alt grubudur. ${ }^{6}$ Tip 3 bebekler, küçük çocuklar, immün sistemi baskılanmış kişiler, kronik hastalar ve yaşlılarda genelde ilkbahar ve yaz aylarında ortaya çıkan ASYE' nin başlıca nedenidir. ${ }^{7,8}$ Tip 4' ün epidemiyolojisi daha az bilinmekte olup, 6 aydan küçük bebeklerde üst ve ASYE'den sorumlu görünmektedir. ${ }^{6}$ Hastamız da immünyetmezlik saptanmamakla beraber, yaşının kısmen küçük olması nedeniyle risk grubuna girmektedir.

Asemptomatik de olsa, çoğu kişi 5 yaşına kadar enfeksiyona yakalanmış olur. Enfeksiyonları sporadik olduğu kadar salgın olarak da görülür. Kuluçka süresi 2-6 gün olup yaşam boyu tekrarlayabilir. Re-enfeksiyon en sık üst solunum yolunu tutar ve klinik olarak daha az şiddetlidir. Deterjan ve ısıya karşı duyarlı olan PİV en fazla 10 saat kadar yüzeyde canlı kalabilir. Son derece bulaşıcı bir virüs olup; damlacıklarla kontaminasyon, nazofarenks salgılarına maruz kalma veya kontamine yüzeylerle temas yoluyla bulaşır. $^{6}$

Serolojik araştırmalar, çocukların \%60’ ının 2 yaşına kadar PİV-3 ile enfekte olduğunu göstermiştir ve bu sayı 4 yaşına kadar \% 80’ e kadar yükselmektedir. ${ }^{9}$ Enfeksiyonlar ve komplikasyonları, yıllık bazda önemli sayıda hastaneye yatış ve ölümden sorumludur. ${ }^{6}$ Virüsün replikasyonunun birincil yeri nazofarinks ve orofarinks olmasına rağmen, rinore/rinit, farenjit, krup (laringo-trakeo-bronşit), bronşiolit ve pnömoni gibi klinik durumlar hastaların hastaneye başvuru nedenleri arasındadır. ${ }^{10}$ Olgumuzda PIV-3 tekrarlayan hışıltıda etyolojik bir nedeni olarak karşımıza çıkmıştır.

Hastaların genellikle ilk belirti olarak hapşırma, burun akıntısı, öksürük gibi üst solunum yolu enfeksiyonuna ait bulguları olur. Ateş subfebril veya yüksek görülebilir. Fizik muayenede akciğerlerde hışıltı, ekspiryum uzaması, sibilan ral duyulabilir ve solunum sıkıntısı, taşipne, retraksiyon, hava hapsi görülebilir. ${ }^{6}$ Laboratuar bulgusu spesifik değildir. Kan sayımında genelde lenfosit hakimiyeti görülür. Hastalık süresince antibiyotik kullanımı sınırlandırmak ve semptomların görüldüğü ilk 48 saat içinde tedaviye antiviral tedavi eklemek doğru ve hızlı tanıda yardımcı olur. ${ }^{6}$ Hastamızda literatürden farklı olarak, lökopeniyle beraber lenfopeniye ek olarak monositoz gözlenmiştir. Kliniğin düzelmesiyle lökosit, lenfosit ve monosit sayıları normal sınırlara girmiştir.

Bunun yanında nazofarengeal sürüntü örneği erken dönemde tanı koymada kullanılan bir tekniktir. ${ }^{6}$ Hastamızda da alınan sürüntü örneğinde PİV- 3 etken olarak saptanıp tedavi semptomatik olarak gerçekleştirilmiştir. Sürüntü örneğinde saptanması ve hastadaki klinik tablonun PIV-3 enfeksiyonu bulgularıyla uyuşması etken ajanın PİV-3 olduğunu düşündürtmüştür. Bu durum, tedavi açısından bir farklılığa yol açmasa da, bu patojenin tekrarlayan ASYE, hışıltı ve çocukluk çağı astım alevlenmelerinde rolü olabileceğini göstermesi açısından önemlidir.

\section{Sonuç}

Parainfluenza virüs enfeksiyonları; çocukluk çağı bronşioliti, astımı ve tekrarlayan hışıltı atakları gibi kronik hava yolu hastalıklarının viral alevlenmelerinin önemli nedenlerinden biri olup, klinisyenler tarafından akılda tutulmalıdır. 
Journal of BSHR 2019;3(3):260-263

ÖZDEMIR, OKUR. Tekrarlayan Hıșltı ve Parainfluenza Tip 3

\section{Kaynaklar}

1. Fitzgerald DA, Kilham HA. Bronchiolitis: assessment and evidence-based management. Med J Aust. 2004;180(8):399-404.

2. Arden KE, McErlean P, Nissen MD, Sloots TP, Mackay IM. Frequent detection of human rhinoviruses, paramyxoviruses, coronaviruses, and bocavirus during acute respiratory tract infections. J Med Virol. 2006;78(9):1232-40.

3. Reed G, Jewett PH, Thompson J, Tollefson S, Wright PF. Epidemiology and clinical impact of parainfluenza virus infections in otherwise healthy infants and young children $<5$ years old. J Infect Dis. 1997;175(4):807-13

4. Waterson AP. Two kinds of myxovirus. Nature 1962;193:1163-4.

5. Glezen WP, Denny FW. Epidemiology of acute lower respiratory disease in children. N Engl J Med 1973;288:498-505.
6. Fox TG, Christenson JC. Influenza and parainfluenza viral infections in children. Pediatr Rev. 2014; 35(6):217-27.

7. Karron $R A$, Wright $P F$, Newman $F K$, et al. A live human parainfluenza type 3 virus vaccine is attenuated and immunogenic in healthy infants and children. J Infect Dis 1995;172:1445-

8. Denny FW, Clyde WA Jr. Acute lower respiratory tract infections in nonhospitalized child ren. J Pediatr. 1986;108(5 Pt 1):635-46.

9. Tsukagoshi H, Ishioka T, Noda $M$, et al. Molecular epidemiology of respiratory viruses in virus-induced asthma. Front Microbiol. 2013;4:1-10.

10. Henrickson KJ. Parainfluenza viruses. Clin Microbiol Rev. 2003;16:242-64. 